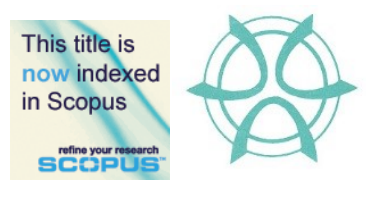

PLANNING MALAYSIA:

Journal of the Malaysian Institute of Planners

VOLUME 17 ISSUE 2 (2019), Page 302 - 311

\title{
PREDICTABILITY OF POSITIVE RELATIONSHIPS THROUGH PERSONAL EMPOWERMENT
}

\author{
Aisyah Abu Bakar', Mariana Mohamed Osman ${ }^{2} \&$ Muhammad Faris Abdullah ${ }^{3}$ \\ ${ }^{1,2,3}$ Kulliyyah of Architecture and Environmental Design \\ INTERNATIONAL ISLAMIC UNIVERSITY MALAYSIA
}

\begin{abstract}
Designers have long adopted the knowledge from the field of psychology to expand architectural space's emotional impacts. Appropriate design strategies can improve and sustain well-being through instilling the sense of empowerment, leading to positive relationships among space occupants. Issue: A large body of the literature has sought to provide a conclusive empirical assessment on the predictability of attitudes and behaviours in positive relationships (PR) through personal empowerment (PE). Purpose: This paper intends to determine the predictability of PR based on PE. Approach: Multiple Correlation and Multiple Linear Regression were conducted to estimate linear associations and parameters of linear equations to predict PR components based on PE items. Findings: Components of PR were predictable by the majority of the PE items and 'monitoring behaviours to suit with situation' was the strongest predictor of PR.
\end{abstract}

Keywords: positive relationship, personal empowerment 
PLANNING MALAYSIA

Journal of the Malaysia Institute of Planners (2019)

\section{INTRODUCTION}

Human interdependence with other humans $(\mathrm{HIH})$ is one of the agents of subjective sustainable well-being (SSWB). HIH is the extent of individuals' abilities to dedicate themselves in their social context in return for SSWB. Personal empowerment (PE) and positive relationships (PR) are dimensions of HIH. Spatial designs support developmental milestones contributing to enhance PE. Some studies have theoretically justified the widely diverse ends and means of PE. While there are claims of PE as enablers of PR, empirical evidence is still lacking. This paper assesses the statistical predictability of PR based on PE.

\section{LITERATURE REVIEW}

Case studies based on articles from selected Asian Journals from the year 2011 onwards highlight conditional factors and potential determinants of Positive Relations (PR). Table 1 summarises these findings.

Table 1 Conditional factors and potential determinants for positive relationships

\begin{tabular}{|c|c|c|}
\hline Conditional Factors (keywords) & Potential Determinants & References \\
\hline $\begin{array}{l}\text { Parenting styles and involvement, authorities } \\
\text { parenting, work-family balance; economic situation } \\
\text { health and safety at home; community involvement; } \\
\text { spirituality; density and number of bedrooms. }\end{array}$ & $\begin{array}{l}\text { Involvement, support, resilience, } \\
\text { time (ability to spend time with } \\
\text { family), and family functioning } \\
\text { (fulfilling roles and) }\end{array}$ & $\begin{array}{l}\text { Noraini, } \\
\text { Gandhi, } \\
\text { Ishak, \& } \\
\text { Wok (2014) } \\
\end{array}$ \\
\hline $\begin{array}{l}\text { husband and wife relations, family relationships, } \\
\text { achievements, economic situations, standard of living, } \\
\text { health, safety, relationship with community, spiritual } \\
\text { practices, and basic amenities. }\end{array}$ & $\begin{array}{l}\text { Functioning, involvement, } \\
\text { resilience, tolerance (acceptance) } \\
\text { and understanding, helpfulness } \\
\text { and time with family }\end{array}$ & $\begin{array}{l}\text { Abu Rahim, } \\
\text { Ishak, Mohd } \\
\text { Shafie, \& } \\
\text { Shafiai } \\
\text { (2013) }\end{array}$ \\
\hline $\begin{array}{l}\text { Settlement areas (urban area), income ( }>\text { RM } 800 \text { ), } \\
\text { marital status (married) and possess social life skills }\end{array}$ & $\begin{array}{l}\text { Care (feeling concern for), } \\
\text { responsibility, and social contact } \\
\text { (communication) }\end{array}$ & $\begin{array}{l}\text { Mohamad et } \\
\text { al. (2013) }\end{array}$ \\
\hline $\begin{array}{l}\text { Resilience (strength to cope in stressful situations), } \\
\text { financial autonomy (financially independent) }\end{array}$ & $\begin{array}{l}\text { Emotional intimacy, tolerance, } \\
\text { responsibility }\end{array}$ & $\begin{array}{l}\text { Shuib et al. } \\
\text { (2013) }\end{array}$ \\
\hline $\begin{array}{l}\text { Gender - women apologize more to the same gender, } \\
\text { while men apologize easier to the opposite gender. } \\
\text { Women have a 'lower threshold of what constitutes } \\
\text { offensive behaviour'. Men tend to apologize when } \\
\text { they believe that they have actually offended someone. }\end{array}$ & $\begin{array}{l}\text { Ability to apologise, humility } \\
\text { (humbleness), modesty } \\
\text { (moderate and unassuming), } \\
\text { compassion (empathy and } \\
\text { sensitivity) }\end{array}$ & $\begin{array}{l}\text { Turiman, } \\
\text { Leong, \& } \\
\text { Hassan } \\
(2013)\end{array}$ \\
\hline $\begin{array}{l}\text { Age and number of children negatively correlate with } \\
\text { marital satisfaction. Marital satisfaction refers to the } \\
\text { perception towards marital relationship in terms of the } \\
\text { marriage as a whole, the husband or wife as a spouse, } \\
\text { the overall relationship with husband or wife, and the } \\
\text { expression of love in the relationship. }\end{array}$ & $\begin{array}{l}\text { Love (deep affection), passion } \\
\text { (enthusiasm for someone), } \\
\text { intimacy (close familiarity), } \\
\text { commitment (sense of } \\
\text { obligation), and communication } \\
\text { (connecting) }\end{array}$ & $\begin{array}{l}\text { Hoesni, } \\
\text { Subhi, } \\
\text { Alavi, \& } \\
\text { Wan } \\
\text { Azreena } \\
(2013) \\
\end{array}$ \\
\hline $\begin{array}{l}\text { Parents' self-esteem (confidence in abilities), family } \\
\text { functioning (involvement and communication), and } \\
\text { temperament (innate and enduring personality traits) }\end{array}$ & $\begin{array}{l}\text { Conducive (encouraging) and } \\
\text { responsive (readily responding) } \\
\text { behaviours }\end{array}$ & $\begin{array}{l}\text { Chiah \& } \\
\text { Baharudin } \\
(2013)\end{array}$ \\
\hline $\begin{array}{l}\text { Parents' personality factors, parent-child relationship } \\
\text { and practices, parental intervention, family sibship } \\
\text { size, peer relationship and academic performance }\end{array}$ & $\begin{array}{l}\text { Extraversion (outgoing) } \\
\text { emotional stability, and } \\
\text { conscientiousness (being careful } \\
\text { or vigilant) }\end{array}$ & $\begin{array}{l}\text { Ha \& Tam } \\
\quad(2013)\end{array}$ \\
\hline $\begin{array}{lcrr}\text { Psychosocial } & \text { well-being } & \text { (connection between } \\
\text { psychological } & \text { experience } & \text { and wider } & \text { social }\end{array}$ & $\begin{array}{l}\text { Problem-solving skills } \\
\text { helpfulness, intimacy, tolerance } \\
\text { and openness in communication }\end{array}$ & $\begin{array}{l}\text { (Demir et } \\
\text { al., 2012) }\end{array}$ \\
\hline
\end{tabular}


Aisyah Abu Bakar, Mariana Mohamed Osman \& Muhammad Faris Abdullah

Personal Empowerment as Determinants of Organisational Opportunity

experience), and social skills (skills facilitating

interaction and communication with others)

Peer-rejection (exclusion from social interaction), isolation (separation from others), criticism (expression of disapproval), strictness (rigidity and stringency), competitions (act of rivalry and supremacy), and emotional dissatisfaction (intense feelings of discontent or feeling disgruntled).

Interaction skills, flexibility (willingness to compromise) cooperativeness (joint action) and nurturance (love, care and attention given to someone)
Vellymalay

(2013)

The findings from the case studies generate three significant components of PR: (i) Tolerance and Compassion (PRa), (ii) Sense of Inclusion (PRb) and (iii) Self-Regulation and Benevolent (PRc).

Table 2 Components and determinants of positive relationships

\begin{tabular}{|c|c|c|c|}
\hline Definition of PR & Components & Items & Code \\
\hline \multirow{9}{*}{$\begin{array}{l}\text { Positive sense of } \\
\text { intimacy, } \\
\text { emotional } \\
\text { responsiveness } \\
\text { and continuous } \\
\text { support expressed } \\
\text { in personal } \\
\text { relationships }\end{array}$} & \multirow{3}{*}{$\begin{array}{l}\text { Tolerance and } \\
\text { Compassion }\end{array}$} & being flexible to differences in opinions & \multirow{3}{*}{$\mathrm{PRa}$} \\
\hline & & confident (not shy) in expressing care and affection & \\
\hline & & $\begin{array}{l}\text { aware and eager to know others' updates } \\
\text { offering emotional support whenever it is needed }\end{array}$ & \\
\hline & \multirow{3}{*}{$\begin{array}{l}\text { Sense of } \\
\text { Inclusion }\end{array}$} & engaging productively in decision making process & \multirow{3}{*}{$\mathrm{PRb}$} \\
\hline & & ensuring others are engaged in decision making process & \\
\hline & & forgiving of others' weaknesses and mistakes & \\
\hline & \multirow{3}{*}{$\begin{array}{l}\text { Self-Regulation } \\
\text { and Benevolent }\end{array}$} & self-conscious of own mistakes and quickly apologies & \multirow{3}{*}{ PRc } \\
\hline & & motivating and assisting others to fulfil their life goals & \\
\hline & & expressing appreciations to others regularly & \\
\hline
\end{tabular}

Personal Empowerment (PE) manifests in the opportunity to exercise control, voice and choice with regards to social surroundings. Qualities adhere to PE include (i) self-motivation with regards to goal orientation, autonomy and self-regulation (Fatimah et al., 2011; Chin et al., 2012; Kok, 2016), (ii) social acceptance and coherence with others (Fatimah, Lukman, Khairudin, Wan Shahrazad, \& Halim, 2011; Nesbit, Jepsen, Demirian, \& Ho, 2012; Kadir, Omar, Desa, \& Yusooff, 2013; Zamani, Khairudin, Sulaiman, Halim, \& Nasir, 2013), and (iii) composure, stability and resilience (Song, Cai, Brown, \& Grimm, 2011; Sulaiman et al., 2013; Sipon, Nasrah, Nazli, Abdullah, \& Othman, 2014).

Table 3 Determinants of personal empowerment

\begin{tabular}{lll}
\hline \multicolumn{1}{c}{ Definition of PE } & Items & Code \\
\hline & \multicolumn{1}{c}{ setting goals and striving to meet goals } & PE1 \\
\cline { 2 - 3 } & striving and working hard even for easy goals & PE2 \\
\cline { 2 - 3 } $\begin{array}{l}\text { Self-esteem in taking control over } \\
\text { life along with sense of composure } \\
\text { to progress in the social } \\
\text { environment }\end{array}$ & monitoring behaviours to suit with situations & PE3 \\
\cline { 2 - 3 } & knowing when somebody is offended & PE4 \\
\cline { 2 - 3 } & ensuring others are comfortable when making deals & PE5 \\
\cline { 2 - 3 } & able to be friendly with distasteful persons when necessary & PE6 \\
\cline { 2 - 3 } & able to work out solutions during stress and difficulties & PE7 \\
\cline { 2 - 3 } & tackling problems efficiently in unexpected conditions & PE8 \\
\cline { 2 - 3 } & feeling energetic for daily routines and activities & PE9 \\
\cline { 2 - 3 } & having hardly distracted and focus mind & PE10 \\
\hline
\end{tabular}


Based on theoretical underpinnings, this research hypothesises that PR components are predictable by PE. The following sections provide empirical evidence the predictability of PRa, PRb and PRc based on PE items.

\section{METHOD}

A sample of 4,315 was gathered after the data screening process. The Malaysian respondents were given an 11-point Likert scale to respond to questionnaire items which include the components of PR and the ten (10) PE items. Pearson correlation analyses were conducted to observe if there were linear associations between the PR components and PE items. Ensuing correlation analyses, multiple linear regression analyses were conducted to estimate parameters of the linear equations used to predict values of PRa, PRb and PRc from PE items.

\section{RESULTS AND DISCUSSION}

At $95 \%$ confidence level, there were statistically significant positive correlations between (i) PRa and each of PE items, (ii) PRb and each of PE items, and (iii) PRc and each of PE items. The null hypotheses claiming there are no statistically significant correlations between (i) PRa and respective PE items, (ii) PRb and respective $\mathrm{PE}$ items, and (iii) $\mathrm{PRc}$ and respective $\mathrm{PE}$ items were all rejected.

Table 4 Multiple Correlations between PE items and PRa, PRb and PRc

$\mathrm{H}_{0}$ There is no statistically significant correlation between PRa and respective PE items

$\mathrm{H}_{0}$ There is no statistically significant correlation between $\mathrm{PRb}$ and respective PE items

$\mathrm{H}_{0}$ There is no statistically significant correlation between PRc and respective PE items

\begin{tabular}{|c|c|c|c|c|c|c|c|c|c|c|c|}
\hline \multicolumn{12}{|c|}{ Correlation Strength Threshold (Dancey \& Reidy, 2004) } \\
\hline $\mathrm{r}$ & 0 & .1 & .2 & .3 & .4 & .5 & .6 & .7 & .8 & 9 & 1 \\
\hline strengt & zero & \multicolumn{3}{|c|}{ weak } & \multicolumn{3}{|c|}{ moderate } & \multicolumn{3}{|c|}{ strong } & perfect \\
\hline DV & Stats & PE1 & PE2 & PE3 & PE4 & PE5 & PE6 & PE7 & PE8 & PE9 & PE10 \\
\hline \multirow{3}{*}{ PRa } & $\mathrm{r}$ & $.494^{* *}$ & $.511^{* *}$ & $.498^{* *}$ & $.470^{* *}$ & $.470^{* *}$ & $.431^{* *}$ & $.442^{* *}$ & $.427^{* *}$ & $.445^{* *}$ & $.405^{* *}$ \\
\hline & $\mathrm{p}$ & .000 & .000 & .000 & .000 & .000 & .000 & .000 & .000 & .000 & .000 \\
\hline & $\mathrm{N}$ & 4315 & 4315 & 4315 & 4315 & 4315 & 4315 & 4315 & 4315 & 4315 & 4315 \\
\hline \multirow{3}{*}{$\mathrm{PRb}$} & $\mathrm{r}$ & $.446^{* *}$ & $.465^{* *}$ & $.461^{* *}$ & $.426^{* *}$ & $.451^{* *}$ & $.382^{* *}$ & $.402^{* *}$ & $.403^{* *}$ & $.419^{* *}$ & $.375^{* *}$ \\
\hline & $\mathrm{p}$ & .000 & .000 & .000 & .000 & .000 & .000 & .000 & .000 & .000 & .000 \\
\hline & $\mathrm{N}$ & 4315 & 4315 & 4315 & 4315 & 4315 & 4315 & 4315 & 4315 & 4315 & 4315 \\
\hline \multirow{3}{*}{ PRc } & $\mathrm{r}$ & $.458^{* *}$ & $.473^{* *}$ & $.480^{* *}$ & $.433^{* *}$ & $.463^{* *}$ & $.386^{* *}$ & $.412^{* *}$ & $.389^{* *}$ & $.420^{* * *}$ & $.351^{* *}$ \\
\hline & $\mathrm{p}$ & .000 & .000 & .000 & .000 & .000 & .000 & .000 & .000 & .000 & .000 \\
\hline & $\mathrm{N}$ & 4315 & 4315 & 4315 & 4315 & 4315 & 4315 & 4315 & 4315 & 4315 & 4315 \\
\hline
\end{tabular}

At 95\% confidence level, there were statistically significant and moderate correlations between PRa

PRa and (i) PE1 ( $\mathrm{r}=.494, \mathrm{p}=.000)$; (ii) PE2 ( $\mathrm{r}=.511, \mathrm{p}=.000)$; (iii) PE3 ( $\mathrm{r}=.498, \mathrm{p}=.000)$; (iv) PE4 ( $\mathrm{r}$ $=.470, \mathrm{p}=.000)$; (v) PE5 ( $\mathrm{r}=.470, \mathrm{p}=.000)$; (vi) PE6 ( $\mathrm{r}=.431, \mathrm{p}=.000)$; (vii) PE7 ( $\mathrm{r}=.442, \mathrm{p}=.000)$; (viii) PE8 $(\mathrm{r}=.427, \mathrm{p}=.000)$; (ix) PE9 $(\mathrm{r}=.445, \mathrm{p}=.000)$; $(\mathrm{x})$ PE01 $(\mathrm{r}=.405, \mathrm{p}=.000)$.

At $95 \%$ confidence level, there were statistically significant and moderate correlations between $\mathrm{PRb}$

$\mathrm{PRb}$ and (i) PE1 ( $\mathrm{r}=.446, \mathrm{p}=.000)$; (ii) PE2 $(\mathrm{r}=.465, \mathrm{p}=.000)$; (iii) PE3 ( $\mathrm{r}=.461, \mathrm{p}=.000)$; (iv) PE4 ( $\mathrm{r}$ $=.426, \mathrm{p}=.000) ;(\mathrm{v})$ PE5 $(\mathrm{r}=.451, \mathrm{p}=.000)$; (vi) PE7 $(\mathrm{r}=.402, \mathrm{p}=.000)$; (vii) PE8 ( $\mathrm{r}=.403, \mathrm{p}=$ 
Aisyah Abu Bakar, Mariana Mohamed Osman \& Muhammad Faris Abdullah

Personal Empowerment as Determinants of Organisational Opportunity

000); (viii) PE9 $(\mathrm{r}=.419, \mathrm{p}=.000)$. Additionally, there were statistically significant and weak correlations between PRb and (ix) PE6 ( $\mathrm{r}=.382, \mathrm{p}=.000)$; $(\mathrm{x})$ PE10 ( $\mathrm{r}=.375, \mathrm{p}=.000)$.

At $95 \%$ confidence level, there were statistically significant and moderate correlations between PRc and (i) PE1 ( $\mathrm{r}=.458, \mathrm{p}=.000)$; (ii) PE2 ( $\mathrm{r}=.473, \mathrm{p}=.000)$; (iii) PE3 ( $\mathrm{r}=.480, \mathrm{p}=.000)$; (iv) PE4 ( $\mathrm{r}$

PRc $=.433, \mathrm{p}=.000)$; (v) PE5 $(\mathrm{r}=.463, \mathrm{p}=.000)$; (vi) PE7 $(\mathrm{r}=.412, \mathrm{p}=.000)$; (vii) PE8 $(\mathrm{r}=.389, \mathrm{p}=$ 000); (viii) PE9 $(\mathrm{r}=.420, \mathrm{p}=.000)$; Additionally, there were statistically significant and weak correlations between PRc and (ix) PE6 ( $\mathrm{r}=.386, \mathrm{p}=.000) ;(\mathrm{x})$ PE10 $(\mathrm{r}=.351, \mathrm{p}=.000)$.

Three (3) multiple regression analyses were carried out to predict the values of each of dependent variables (i) PRa, (ii) PRb and (iii) PRc given the set of PE explanatory variables (PE1, PE2, PE3, PE4, PE5, PE6, PE7, PE8, PE9, and PE10).

Table 5 Multiple Linear Regression - PE predicting PRa

$$
\mathrm{H}_{0}
$$

There will be no significant prediction of PRa by PE1, PE2, PE3, PE4, PE5, PE6, PE7, PE8, PE9 and PE10

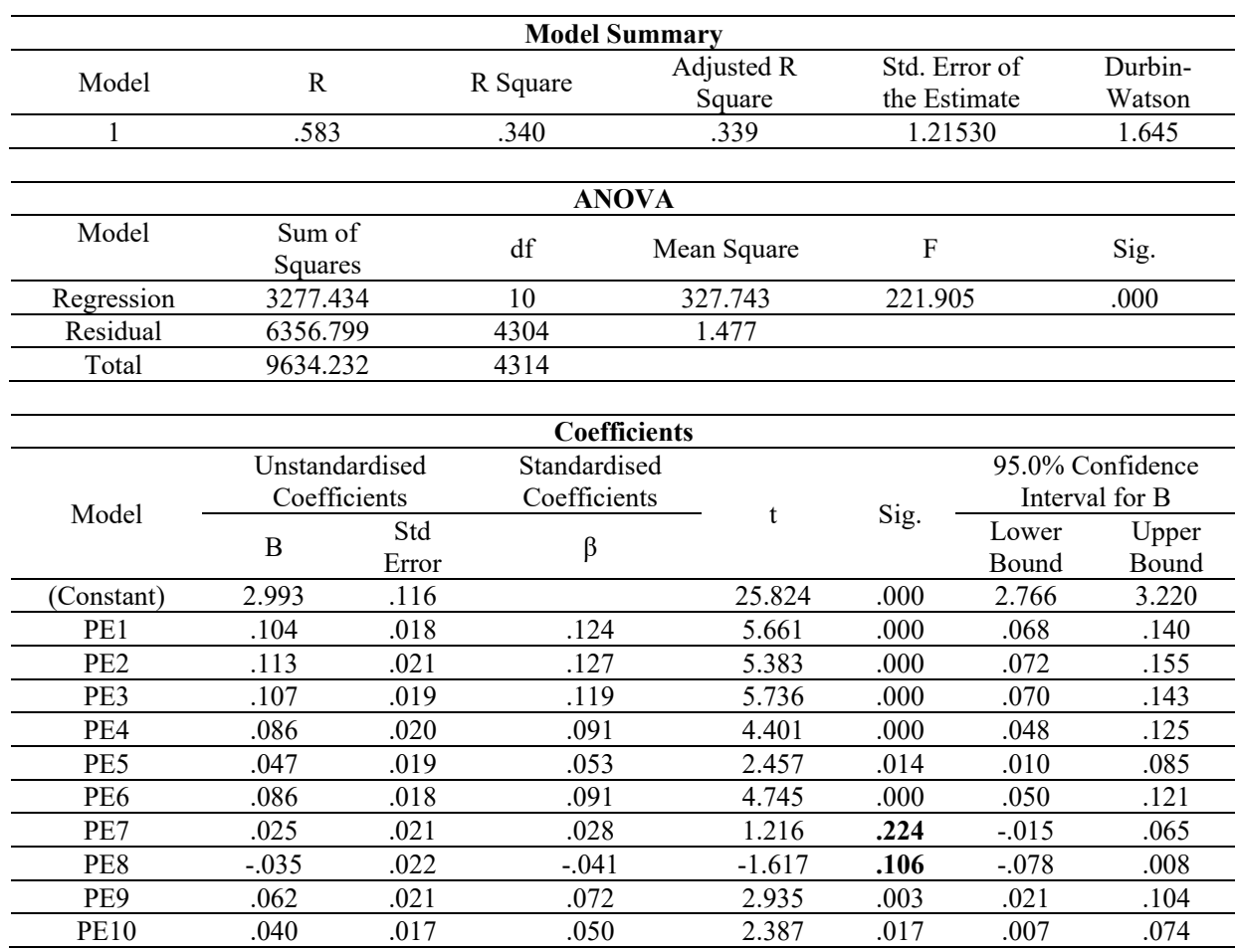

A multiple regression was generated to predict PRa based on PE items. $R$ value of .583 indicated an acceptable level of prediction $(R>0.5)$. The DurbinWatson statistic was 1.645 which is between 1.5 and 2.5 and therefore the data was not autocorrelated. A significant regression equation was found, $F(10,4304)$ 
$=221.905, \mathrm{p}=.000$, with an $\mathrm{R}^{2}$ of .340 ; indicating that the proportion of variance in PRa that can be explained by PE items was $34 \%$.

At $95 \%$ confidence level, PE1 $(\mathrm{B}=.104, \mathrm{t}=5.661, \mathrm{p}=.000)$, PE2 (B $=$ $.113, \mathrm{t}=5.383, \mathrm{p}=.000)$, PE3 $(\mathrm{B}=.107, \mathrm{t}=5.736, \mathrm{p}=.000)$, PE4 $(\mathrm{B}=.086, \mathrm{t}=$ $4.401, \mathrm{p}=.000)$, PE5 $(\mathrm{B}=.047, \mathrm{t}=2.457, \mathrm{p}=.014)$, PE6 $(\mathrm{B}=.086, \mathrm{t}=4.745, \mathrm{p}$ $=.000)$, PE9 $(\mathrm{B}=.062, \mathrm{t}=2.935, \mathrm{p}=.003)$ and PE10 $(\mathrm{B}=.040, \mathrm{t}=2.387, \mathrm{p}=.017)$ were significant predictors of PRa. On the contrary, it was found that PE7 (B = $.025, \mathrm{t}=1.216, \mathrm{p}=.224)$ and PE8 $(\mathrm{B}=-.035, \mathrm{t}=-1.617, \mathrm{p}=.106)$ were not significant predictors of PRa.

Personal Empowerment (PE) items significantly account for 34\% of Tolerance and Compassion (PRa). Eight (8) of PE items were significant predictors of PRa.

Table 6 Multiple Linear Regression - PE predicting PRb

\begin{tabular}{|c|c|c|c|c|c|c|c|}
\hline \multicolumn{8}{|c|}{$\mathrm{H}_{0}$} \\
\hline \multicolumn{8}{|c|}{ There will be no significant prediction of PRb by PE1, PE2, PE3, PE4, PE5, PE6, PE7, PE8, PE9 and PE10 } \\
\hline \multicolumn{8}{|c|}{ Model Summary } \\
\hline Model & \multicolumn{2}{|c|}{$\mathrm{R}$} & R Square & $\begin{array}{l}\text { Adjusted R } \\
\text { Square }\end{array}$ & \multicolumn{2}{|c|}{$\begin{array}{l}\text { Std. Error of } \\
\text { the Estimate }\end{array}$} & $\begin{array}{l}\text { Durbin- } \\
\text { Watson }\end{array}$ \\
\hline 1 & \multicolumn{2}{|c|}{.536} & .287 & .286 & \multicolumn{2}{|c|}{1.31404} & 1.759 \\
\hline \multicolumn{8}{|c|}{ ANOVA } \\
\hline Model & \multicolumn{2}{|c|}{$\begin{array}{l}\text { Sum of } \\
\text { Squares }\end{array}$} & df & Mean Square & \multicolumn{2}{|c|}{ F } & Sig. \\
\hline Regression & \multicolumn{2}{|c|}{2998.190} & 10 & 299.819 & \multicolumn{2}{|c|}{173.637} & .000 \\
\hline Residual & \multicolumn{2}{|c|}{7431.725} & 4304 & 1.727 & & & \\
\hline Total & \multicolumn{2}{|c|}{10429.915} & 4314 & & & & \\
\hline \multicolumn{8}{|c|}{ Coefficients } \\
\hline \multirow{2}{*}{ Model } & \multicolumn{2}{|c|}{$\begin{array}{l}\text { Unstandardised } \\
\text { Coefficients }\end{array}$} & $\begin{array}{l}\text { Stand } \\
\text { Coef }\end{array}$ & \multirow{2}{*}{$\mathrm{t}$} & \multirow{2}{*}{ Sig. } & \multicolumn{2}{|c|}{$\begin{array}{c}95.0 \% \text { Confidence } \\
\text { Interval for B }\end{array}$} \\
\hline & B & Std Error & & & & $\begin{array}{l}\text { Lower } \\
\text { Bound }\end{array}$ & $\begin{array}{l}\text { Upper } \\
\text { Bound }\end{array}$ \\
\hline (Constant) & 3.226 & .125 & & 25.747 & .000 & 2.981 & 3.472 \\
\hline PE1 & .081 & .020 & & 4.062 & .000 & .042 & .120 \\
\hline PE2 & .099 & .023 & & 4.335 & .000 & .054 & .143 \\
\hline PE3 & .108 & .020 & & 5.362 & .000 & .068 & .147 \\
\hline PE4 & .051 & .021 & & 2.406 & .016 & .009 & .093 \\
\hline PE5 & .117 & .021 & & 5.637 & .000 & .076 & .158 \\
\hline PE6 & .037 & .020 & & 1.912 & .056 & -.001 & .076 \\
\hline PE7 & -.006 & .022 & & -.254 & .799 & -.049 & .038 \\
\hline PE8 & .010 & .024 & & .412 & .680 & -.037 & .056 \\
\hline PE9 & .070 & .023 & & 3.042 & .002 & .025 & .115 \\
\hline PE10 & .035 & .018 & & 1.895 & .058 & -.001 & .071 \\
\hline
\end{tabular}

A multiple regression was generated to predict $\mathrm{PRb}$ based on PE items. $R$ value of .536 indicated an acceptable level of prediction $(R>0.5)$. The DurbinWatson statistic was 1.759 which is between 1.5 and 2.5 and therefore the data was not autocorrelated. A significant regression equation was found, $F(10,4304)$ 
Aisyah Abu Bakar, Mariana Mohamed Osman \& Muhammad Faris Abdullah

Personal Empowerment as Determinants of Organisational Opportunity

$=173.637, \mathrm{p}=.000$, with an $\mathrm{R}^{2}$ of .287 ; indicating that the proportion of variance in PRb that can be explained by PE items was $28.7 \%$.

At $95 \%$ confidence level, PE1 $(\mathrm{B}=.081, \mathrm{t}=4.062, \mathrm{p}=.000)$, PE2 $(\mathrm{B}=$ $.099, \mathrm{t}=4.335, \mathrm{p}=.000)$, PE3 $(\mathrm{B}=.108, \mathrm{t}=5.362, \mathrm{p}=.000)$, PE4 $(\mathrm{B}=.051, \mathrm{t}=$ $2.406, \mathrm{p}=.000)$, PE5 $(\mathrm{B}=.117, \mathrm{t}=3.042, \mathrm{p}=.002)$, and PE9 $(\mathrm{B}=.070, \mathrm{t}=2.935$, $\mathrm{p}=.003$ ) were significant predictors of $\mathrm{PRb}$. On the contrary, it was found that PE6 ( $\mathrm{B}=.037, \mathrm{t}=1.912, \mathrm{p}=.056)$, PE7 $(\mathrm{B}=-.066, \mathrm{t}=-.254, \mathrm{p}=.799)$, PE8 (B $=.010, \mathrm{t}=.412, \mathrm{p}=.680)$ and PE10 $(\mathrm{B}=.035, \mathrm{t}=1.895, \mathrm{p}=.058)$ were not significant predictors of $\mathrm{PRb}$.

Personal Empowerment (PE) items significantly account for $28.7 \%$ of Sense of Inclusion (PRb). Six (6) of PE items were significant predictors of PRb.

Table 7 Multiple Linear Regression - PE predicting PRc

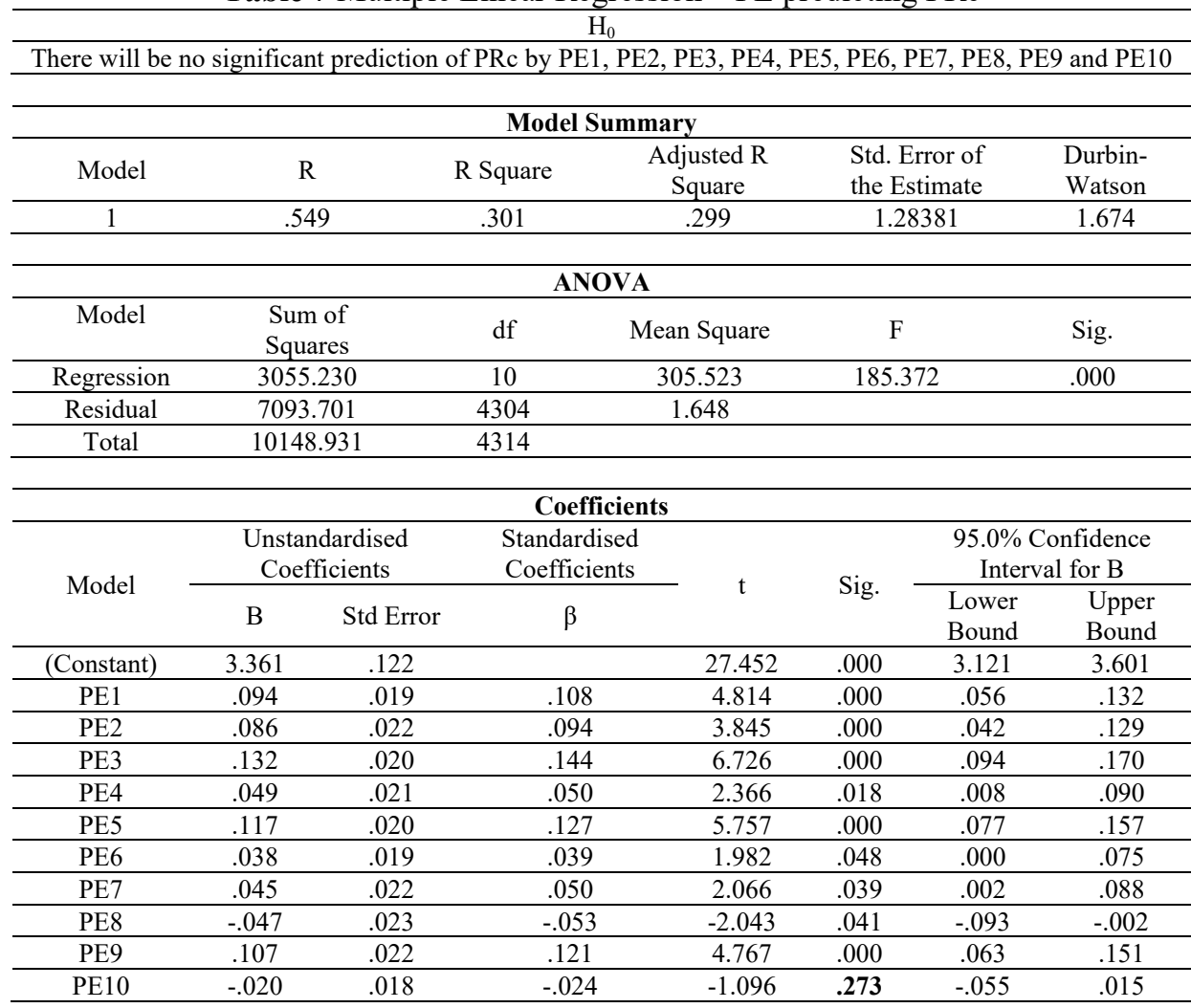

A multiple regression was generated to predict PRc based on PE items. $\mathrm{R}$ value of .549 indicated an acceptable level of prediction $(\mathrm{R}>0.5)$. The DurbinWatson statistic was 1.674 which is between 1.5 and 2.5 and therefore the data was not autocorrelated. A significant regression equation was found, $F(10,4304)$ 
$=185.372, \mathrm{p}=.000$, with an $\mathrm{R}^{2}$ of .301 ; indicating that the proportion of variance in PRc that can be explained by PE items was $30.1 \%$.

At $95 \%$ confidence level, PE1 $(\mathrm{B}=.094, \mathrm{t}=4.814, \mathrm{p}=.000)$, PE2 (B $=$ $.086, \mathrm{t}=3.845, \mathrm{p}=.000)$, PE3 $(\mathrm{B}=.132, \mathrm{t}=6.726, \mathrm{p}=.000)$, PE4 $(\mathrm{B}=.049, \mathrm{t}=$ $2.366, \mathrm{p}=. .018)$, PE5 $(\mathrm{B}=.117, \mathrm{t}=5.757, \mathrm{p}=.000)$, PE6 $(\mathrm{B}=.038, \mathrm{t}=1.982, \mathrm{p}$ $=.048)$, PE7 $(\mathrm{B}=.045 \mathrm{t}=2.066, \mathrm{p}=.039)$, PE8 $(-.047, \mathrm{t}=-2.043, \mathrm{p}=.041)$ and PE9 $(\mathrm{B}=.107, \mathrm{t}=4.767, \mathrm{p}=.000)$ were significant predictors of PRc. It was found that PE10 $(B=-.020, t=-1.096, p=.273)$ was not significant predictor of PRc.

Personal Empowerment (PE) items significantly account for $30.1 \%$ of Self-Regulation and Benevolent (PRc). Nine (9) of PE items were significant predictors of PRc.

Table 8 Summary of findings

\begin{tabular}{|c|c|c|c|c|c|c|c|}
\hline & & \multicolumn{6}{|c|}{ IV (Predictor Variables) - $\beta$} \\
\hline & & PE1 & PE2 & PE3 & PE4 $\quad$ PE5 & $\begin{array}{ll}\text { PE6 } & \text { PE7 } \\
\end{array}$ & PE10 \\
\hline \multirow{3}{*}{$\begin{array}{l}\text { DV } \\
\text { (Outcome } \\
\text { Variables) }\end{array}$} & PRa & $.124 \checkmark$ & $.127 \checkmark$ & $.119 \checkmark$ & $.091 \checkmark$ & $.028 \times-.041 \times .072 \checkmark$ & $.050 \checkmark$ \\
\hline & $\mathrm{PRb}$ & $.092 \checkmark$ & $.107 \checkmark$ & $.116 \checkmark$ & $.052 \checkmark$ & $.038 \times-.006 \times \quad .011 \times \quad .078 \checkmark$ & $.042 X$ \\
\hline & PRc & $.108 \checkmark$ & $.094 \sqrt{ }$ & $.144 \checkmark$ & $.050 \checkmark$ & $\begin{array}{lllll}.039 \checkmark & .050 \checkmark & -.053 \checkmark & .121 \checkmark\end{array}$ & $-.024 X$ \\
\hline \multicolumn{8}{|c|}{$\checkmark=$ statistically significant predictor; $\boldsymbol{X}=$ not statistically significant predictor } \\
\hline DV & \multicolumn{5}{|c|}{ Indicators } & \multirow{2}{*}{$\begin{array}{ll}\text { IV } & \text { Top 3 Strongest Predictors } \\
\text { PE2 } & \begin{array}{l}\text { striving and working hard even } \\
\text { for easy goals }\end{array} \\
\end{array}$} & $\beta$ \\
\hline \multirow{3}{*}{$\begin{array}{l}\text { PRa } \\
\text { Tolerance } \\
\text { and } \\
\text { Compassion }\end{array}$} & \multirow{3}{*}{\multicolumn{5}{|c|}{$\begin{array}{l}\text { - being flexible to differences in opinions } \\
\text { - confident (not shy) in expressing care and } \\
\text { affection } \\
\text { - aware and eager to know others' updates } \\
\text { - offering emotional support whenever it is } \\
\text { needed }\end{array}$}} & & .127 \\
\hline & & & & & & PE1 $\begin{array}{l}\text { setting goals and striving to meet } \\
\text { goals }\end{array}$ & .124 \\
\hline & & & & & & $\begin{array}{l}\text { PE3 } \begin{array}{l}\text { monitoring behaviours to suit } \\
\text { with situations }\end{array} \\
\end{array}$ & .119 \\
\hline & - en & ging pro & ductivel & in decis & ion making & $\begin{array}{l}\text { PE5 ensuring others are comfortable } \\
\text { when making deals }\end{array}$ & .126 \\
\hline Sense of & - en & ring oth & rs are er & gaged in & decision & $\begin{array}{l}\text { PE3 } \begin{array}{l}\text { monitoring behaviours to suit } \\
\text { with situations }\end{array} \\
\end{array}$ & .116 \\
\hline & - for & iving of & & & s and mistakes & $\begin{array}{l}\text { PE2 striving and working hard even } \\
\text { for easy goals }\end{array}$ & .107 \\
\hline $\begin{array}{l}\text { PRe } \\
\text { Self- }\end{array}$ & - $\begin{array}{cl}\mathrm{sel} \\
\mathrm{ap}\end{array}$ & $\begin{array}{l}\text { conscio } \\
\text { ogies }\end{array}$ & s of owr & mistake & and quickly & $\begin{array}{l}\text { PE3 } \begin{array}{l}\text { monitoring behaviours to suit } \\
\text { with situations }\end{array} \\
\end{array}$ & .144 \\
\hline Regulation & - $\mathrm{mo}$ & vating a & d assist & ig other & to fulfil their & $\begin{array}{l}\text { PE5 } \begin{array}{l}\text { ensuring others are comfortable } \\
\text { when making deals }\end{array} \\
\end{array}$ & .127 \\
\hline Benevolent & & & & ns to otl & ers regularly & $\begin{array}{l}\text { PE9 } \begin{array}{l}\text { feeling energetic for daily } \\
\text { routines and activities }\end{array} \\
\end{array}$ & .121 \\
\hline
\end{tabular}

The empirical assessments indicate that the majority of PE items significantly account for $\mathrm{PRa}, \mathrm{PRb}$ and PRc. PE3 which denoted 'monitoring behaviours to suit with situations' was in the top three strongest predictors for all components of PR. Thus implying that the ability to 'fit in' in the social sphere highly encourage and enable more positive behaviours in relational well-being. Manoeuvring emotions and behaviours mindfully and rationally demands the commitment to continually watch over personal thoughts and feelings as well as 
Aisyah Abu Bakar, Mariana Mohamed Osman \& Muhammad Faris Abdullah

Personal Empowerment as Determinants of Organisational Opportunity

reactions of others. Architectural design can enhance attentive communications and receptive interactions through space sizes and layouts, furniture organisations, colour choices and many other design strategies. Designers indirectly enrich positive relationships through empowering space occupants, therefore leading to positive relationships and sustained well-being.

\section{CONCLUSION}

HIH in SSWB deems well-being that is achievable through a supportive and congruent interaction system. This paper proves that positive relationships are achievable through personal empowerment. The future direction of this research involves statistical modelling on the constructs described in this paper.

\section{ACKNOWLEDGEMENT}

This research was supported by Post-Doctoral Fellow under Research Initatives Grant Scheme (RIGS-PDF), International Islamic University Malaysia (project title: RPDF19-005-0015)

\section{REFERENCES}

Abu Rahim, M. A. R., Ishak, I., Mohd Shafie, S. A., \& Shafiai, R. M. (2013). Factors influencing family life satisfaction among parents in Malaysia: The Structural Equation Modeling Approach (SEM). Journal of Humanities and Social Sciences, $17(4), 78-85$.

Chiah, W. Y., \& Baharudin, R. (2013). Parenting behaviour of mothers, adolescents' social emotional adjustments and their correlates in intact and non-intact Malay families in Kuala Lumpur. Pertanika Journal of Social Science and Humanities, 21(4), 1431-1446.

Dancey, C., \& Reidy, J. (2004) Statistics without maths for psychology: Ssing SPSS for Windows. London: Prentice Hall.

Fatimah, O., Lukman, Z. M., Khairudin, R., Wan Shahrazad, W. S., \& Halim, F. W. (2011). Procrastination's relation with fear of failure, competence expectancy and intrinsic motivation. Pertanika Journal of Social Science and Humanities, 19(Special), 123-127.

Ha, T. S., \& Tam, C. L. (2013). Relationships of birth order, parent-child relationship, personality, and academic performance. Pertanika Journal of Social Science and Humanities, 21(1), 44-52.

Hoesni, S. M., Subhi, N., Alavi, K., \& Wan Azreena, W. J. (2013). Exploring love and marital satisfaction among married Malay males. Pertanika Journal of Social Science and Humanities, 21(December), 59-68.

Kadir, N. B. A., Omar, F., Desa, A., \& Yusooff, F. (2013). Secure style, PWB-related gratitude and SWB-related engagement as predictors of affect balance among social science students in Malaysia: A pilot study. Pertanika Journal of Social Science and Humanities, 21, 85-98.

Mohamad, M. S., Hoesni, S. M., Subhi, N., Chong, S. T., Sarnon, N., \& Nen, S. (2013). Family experiences of caring among caregivers of schizophrenia patients. Pertanika Journal of Social Science and Humanities, 21(4), 1633-1644. 
Nesbit, P. L., Jepsen, D., Demirian, S., \& Ho, J. (2012). Extending self-leadership research to the East: Measurement equivalence of the Chinese and English versions of the MSLQ. Asian Journal of Social Psychology, 15(2), 101-111.

Noraini, M. N., Gandhi, A. D., Ishak, I., \& Wok, S. (2014). Development of indicators for family well- being in Malaysia. Social Indicators Research, 115(1), 279-318.

Shuib, R., Endut, N., Ali, S. H., Osman, I., Abdullah, S., Oon, S. W., ...\& Shahrudin, S. S. H. (2013). Domestic violence and women's well-being in Malaysia: issues and challenges conducting a national study using the WHO multi-country questionnaire on women's health and domestic violence against women. Procedia - Social and Behavioral Sciences, 91, 475-488.

Sipon, S., Nasrah, S. K., Nazli, N. N. N. N., Abdullah, S., \& Othman, K. (2014). Stress and religious coping among flood victims. Procedia - Social and Behavioral Sciences, 140, 605-608.

Song, H., Cai, H., Brown, J. D., \& Grimm, K. J. (2011). Differential item functioning of the Rosenberg Self-Esteem Scale in the US and China: Measurement bias matters. Asian Journal of Social Psychology, 14(3), 176-188.

Sulaiman, W. S. W., Kadir, N. B. A., Halim, F. W., Omar, F., Latiff, R. A., \& Sulaiman, W. S. W. (2013). Structural relations between personality traits, coping strategy, social support and well-being among adolescents. Pertanika Journal of Social Science and Humanities, 21 (December), 121-134.

Turiman, S., Leong, A., \& Hassan, F. (2013). Are men more apologetic than women? Pertanika Journal of Social Science and Humanities, 21(3), 953-964.

Vellymalay, S. K. N. (2013). A case study on friendship, loneliness and social dissatisfaction among preschool children. Pertanika Journal of Social Science and Humanities, 21(4), 1379-1393.

Zamani, Z. A., Khairudin, R., Sulaiman, W. S. W., Halim, F. W., \& Nasir, R. (2013)

Relationship between achievement motivation and personality among pre and postindependence Malaysian Malays. Pertanika Journal of Social Science and Humanities, 21 (December), 135-142

Received: $12^{\text {th }}$ January 2019. Accepted: $2^{\text {nd }}$ August 2019 